\title{
Absolute Isotopic Abundance Ratios of Common, Equal-Atom, and Radiogenic Lead Isotopic Standards
}

\author{
E. J. Catanzaro, T. J. Murphy, W. R. Shields, and E. L. Garner \\ Institute for Materials Research, National Bureau of Standards, Washington, D.C. 20234
}

(February 28, 1968)

\begin{abstract}
Absolute values have been obtained for the isotopic abundance ratios of common, equal-atom, and radiogenic lead isotopic standards using solid-sample mass spectrometry. Samples of known ${ }^{208} \mathrm{~Pb} /{ }^{206} \mathrm{~Pb}$ ratio, prepared from nearly pure separated ${ }^{206} \mathrm{~Pb}$ and ${ }^{208} \mathrm{~Pb}$ solutions, were used to calibrate the mass spectrometers.
\end{abstract}

Key Words: Absolute ratios, abundance, isotopic standards, lead.

\section{Introduction}

The NBS is conducting a long-term program of absolute isotopic abundance ratio and physical atomic - weight determinations, using solid-sample mass spectrometry. Previous elements studied include silver [1], ${ }^{1}$ chlorine [2], copper [3], bromine [4], chromium [5], and magnesium [6]. The present work extends the study to lead.

The extreme isotopic variability of natural lead is 'well authenticated. It results from the fact that $\checkmark{ }^{206} \mathrm{~Pb},{ }^{207} \mathrm{~Pb}$, and ${ }^{208} \mathrm{~Pb}$ are continually being formed by the decay of ${ }^{238} \mathrm{U},{ }^{235} \mathrm{U}$, and ${ }^{232} \mathrm{Th}$, respectively. ${ }^{204} \mathrm{~Pb}$ is nonradiogenic and is used as a fiduciary mark for the separation of the "common" and "radiogenic" portions of natural lead samples. A full discussion of natural lead isotope abundance variations is given by Russell and Farquhar [7].

The purpose of the present study was to establish the absolute isotopic compositions of three lead standards which cover the usual range of natural isotopic values, so that all future lead isotope measurements could be put on an absolute scale. Previous measurements, by numerous laboratories throughout the world, could only be considered relative because there has been no systematic attempt to calibrate instruments and techniques.

In addition, the NBS standard samples, which are distributed for a relatively nominal fee (see appendix), are very high purity lead metal and may also be used as gravimetric standards.

A preliminary study, which was concerned only with the determination of the absolute isotopic com-

\footnotetext{
' Figures in brackets indicate the literature references at the end of this paper.
}

positions of three common lead samples used as references by geochemists, has already been published [8].

The mass spectrometers used in this study were calibrated for bias by the use of samples of known ${ }^{208} \mathrm{~Pb} /{ }^{206} \mathrm{~Pb}$ ratio prepared from nearly pure separated ${ }^{206} \mathrm{~Pb}$ and ${ }^{208} \mathrm{~Pb}$ solutions. The collector and recorder systems used in this laboratory have been designed so that any biases they might contribute are constant. The only "random" bias associated with the isotopic ratio measurements is due to the mass-dependent fractionation of the isotopes during ionization, and this bias is independent of the isotopic composition of the samples. Thus, for each instrumental system used in this study, a single experimentally determined correction factor is valid over the entire range of isotopic compositions measured.

The fact that each mass spectrometer used in this study requires only a single correction factor for source discrimination has been proven by numerous systems calibrations performed mainly with a series of uraniumisotope standards (see appendix), with ${ }^{235} \mathrm{U} /{ }^{238} \mathrm{U}$ ratios ranging from $1 / 20$ to $20 / 1$. A "systems" calibration, as opposed to a "point" calibration in which only one isotopic ratio standard is used, is always necessary for an instrument which is to be used on an element with more than one isotopic ratio. In this laboratory a uranium-isotope systems calibration is performed on each instrument as soon as it is completed, or modified, and before it is ever used in a research project. In addition, whenever feasible, a partial systems calibration is also performed with widely differing isotopic standards of the element under study. For example, partial systems calibrations have been performed with copper [3] and magnesium [6]. In the 
present study the systems calibration was rechecked and verified by comparing the results for calibration mixes with ${ }^{208} \mathrm{~Pb} /{ }^{206} \mathrm{~Pb}=1.0$ and ${ }^{208} \mathrm{~Pb} /{ }^{206} \mathrm{~Pb}=2.1$. It is not practicable to prepare standards of more than two isotopes, because the propagation of isotopic composition uncertainty involved in mixing more than two isotope solutions would greatly decrease the accuracy of the calculated ratios.

\section{Experimental Procedure}

\subsection{Mass Spectrometry}

Isotopic measurements of the calibration mixes and standard samples were made with three different single-stage solid-sample mass spectrometers. Two instruments (\#1 and \#3), used by operator I, are identical in all aspects and the third (\#2), used by operator II, differed only in that it has an in-line beam valve on the tube. All three instruments have a 12 -in radius of curvature $68^{\circ}$ analyzer tube and $60^{\circ}$ sector magnet, and all three have Z-lenses in the source assembly [9]. Triple-filament sources were used; with rheniumribbon $(1 \times 30$ mil) sample filaments and a platinumribbon $(1 \times 30 \mathrm{mil})$ ionizing filament [10].

The samples were prepared to a concentration of $25 \mathrm{mg}$ of $\mathrm{Pb}$ per milliliter of 2 percent $\mathrm{HNO}_{3}$, and were mounted on the sample filaments by mixing, on the filaments, one drop each of the sample solution $(\sim 250 \mu \mathrm{g} \mathrm{Pb})$ and of a 10 percent $\mathrm{NH}_{4} \mathrm{OH}$ solution. The precipitated $\mathrm{Pb}(\mathrm{OH})_{2}$ was dried with a heat lamp and a $1.2 \mathrm{~A}$ current $(5 \mathrm{~min})$. The mass spectrometric analysis was begun when the tube pressure was $<1 \times 10^{-7}$ torr. An accelerating voltage of $10 \mathrm{kV}$ was used and no memory or background signals were ever noted. Source assemblies were dismantled and cleaned between the analyses of the different groups of samples with widely differing isotopic compositions. A detailed description of the mass spectrometric procedure is given by Catanzaro [8].

A small amount of isotopic fractionation generally occurs during an analysis; the ${ }^{208} \mathrm{~Pb} /{ }^{206} \mathrm{~Pb}$ ratio generally increases by about 0.03 percent during the datataking period of an analysis $(24 \mathrm{~min})$. To minimize the effect of this fractionation, all analyses were made in an identical manner; data were always taken during the same time interval, and the total lead ion signal was always kept within strict limits (3 to $5 \times 10^{-11}$ A).

\subsection{Preparation of the Separated Lead Isotope Solutions}

Approximately $2 \mathrm{~g}$ each of electromagnetically separated lead isotopes, ${ }^{206} \mathrm{~Pb}$ and ${ }^{208} \mathrm{~Pb}$, in the form of lead nitrate, $\mathrm{Pb}\left(\mathrm{NO}_{3}\right)_{2}$, were obtained from the Isotopes Division, Oak Ridge National Laboratory of the Union Carbide Nuclear Company. The ${ }^{206} \mathrm{~Pb}\left(\mathrm{NO}_{3}\right)_{2}$ was designated series JV, sample 1186(z); and the ${ }^{208} \mathrm{~Pb}\left(\mathrm{NO}_{3}\right)_{2}$ was designated series MA, sample 1456(a). The certificate of analysis accompanying each sample indicated a high degree of chemical purity. These samples were further analyzed by the Spectrochemical Analysis Section at the National Bureau of Standards by quantitiative emission spectrography. The results of the analyses are shown in table 1. Since the lead concentrations of solutions of the lead isotopes were to be determined by a method based on the precipitation of lead chromate $\left(\mathrm{PbCrO}_{4}\right)$ only those elements forming relatively insoluble chromates would cause errors in the determinations. These were the elements for which quantitative values or limits of detection were established. It was estimated that the maximum possible contamination of the lead isotope samples would be 0.002 percent for the ${ }^{206} \mathrm{~Pb}$ isotope and 0.004 percent for the ${ }^{208} \mathrm{~Pb}$ isotope based on the sum of amounts of the detected elements and limits of detection for the others. These concentrations were too low to cause significant error in the lead determinations so it was not necessary to further purify the isotope samples.

TABLE 1. Results of spectrochemical analy. sis of lead isotope samples

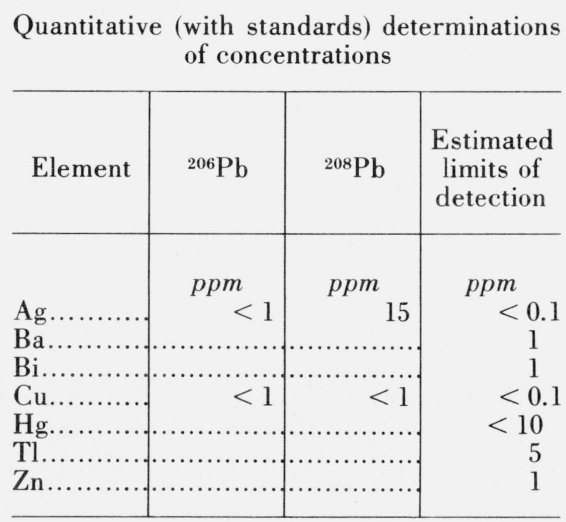

NOTES: .., not detected; $<$, less than.

Solutions of each separated lead isotope were prepared as follows: the lead isotope as lead nitrate (about $3.1 \mathrm{~g})$ was dissolved in about $20 \mathrm{ml}$ of water and $1 \mathrm{ml}$ of ultrapure grade nitric acid was added to this solution. The resulting solution was filtered and the filtrate was transferred to a $100 \mathrm{ml}$ volumetric flask whose neck had been cut off so that only about $1 \mathrm{~cm}$ remained. Enough water was added to bring the final volume to about $65 \mathrm{ml}$. The solution was thoroughly mixed by swirling for several minutes and the flask was sealed with a rubber serum septum. (The total weight of the flask, solution, and septum was kept below $100 \mathrm{~g}$ so that a semimicro balance could be used for weighings.)

The two solutions prepared in this manner were designated "Pb 206" solution and " $\mathrm{Pb} 208$ " solution, respectively.

\subsection{Lead Concentration of the Separated Isotope Solutions}

A search of the chemical literature has shown that there is a need for a high precision-high accuracy method for the determination of lead. A method has 
been developed which is based on the precipitation of lead chromate with a small excess of potassium dichromate and spectrophotometric determination of the excess chromate. This method takes advantage of the precise analysis of NBS Standard Reference Material 139b, potassium dichromate, which has been shown to be $99.977 \pm 0.003$ percent [11].

The flasks containing the solutions of the separated isotopes and a tare flask were placed in the case of a semimicro balance and allowed to stand overnight to insure thermal equilibrium. The flasks and contents were then weighed on the balance to $\pm 0.02 \mathrm{mg}$. Samples were withdrawn from each flask by inserting a platinum needle attached to a glass hypodermic syringe through the rubber septum and withdrawing the desired amount of solution. A second needle which just punctured the septum served as a vent. The syringe and needle were then washed with distilled water and the washings were combined with the withdrawn sample. The weight of the sample withdrawn was determined from the weight of the flask before and after withdrawal of solution.

Four samples of from 7.8 to $8.4 \mathrm{~g}$ each were withdrawn from each solution by this method for the purpose of determining the lead concentrations of the "Pb 206" solution and the "Pb 208" solution. Each sample was treated as follows: two milliliters of perchloric acid was added and the solution was evaporated to dryness at low heat on a hot plate. The residue was dissolved in a small amount of water and the resulting solution was again evaporated to dryness at low heat on a hot plate. This procedure completely freed the salt from nitrate ion which was found to interfere with the method by forming a lead-potassium-nitrate complex [12] which caused low results. The repeated evaporation also freed the salt from excess perchloric acid.

A 100 to $400 \mu \mathrm{g}$ excess of potassium dichromate, $\mathrm{K}_{2} \mathrm{Cr}_{2} \mathrm{O}_{7}$, over the amount needed to stoichiometrically precipitate lead chromate, $\mathrm{PbCrO}_{4}$, was accurately weighed on a microbalance. The potassium dichromate used was NBS Standard Reference Material 139b which has been shown to have an assay value of $99.977 \pm 0.003$ percent [11]. This weight was corrected for assay of the $\mathrm{K}_{2} \mathrm{Cr}_{2} \mathrm{O}_{7}$ and for the bouyancy effect of air.

The potassium dichromate was transferred to a $100 \mathrm{ml}$ beaker and dissolved in about $30 \mathrm{ml}$ of water. This solution was titrated with dilute ammonium hydroxide $(1+99)$ to convert dichromate ion, $\mathrm{Cr}_{2} \mathrm{O}_{7}{ }^{--}$, to chromate ion, $\mathrm{CrO}_{4}{ }^{--}$. The end point of this titration was noted by comparing the color to the yellow color of a potassium chromate solution of the same concentration. A Teflon enclosed magnetic stirring bar was added and the solution was stirred magnetically.

The solution containing the isotopic lead sample was slowly added to the chromate solution and the beaker was thoroughly washed into this solution. The $p \mathrm{H}$ of this solution was adjusted to 2.5 with $(1+9) \mathrm{NH}_{4} \mathrm{OH}$ and finally to between 4.5 and 6.5 with $(1+99) \mathrm{NH}_{4} \mathrm{OH}$. The $p \mathrm{H}$ was monitored with a $p \mathrm{H}$ meter using a glasscalomel electrode system. The precipitate and solution was allowed to stand for $1 \mathrm{hr}$ and then filtered through fine filter paper. The filtrate was caught in a $100 \mathrm{ml}$ volumetric flask. After the precipitate was washed with a small volume of water, the filtrate was diluted to exactly $100 \mathrm{ml}$. One pellet of ACS grade potassium hydroxide, about $0.2 \mathrm{~g}$, was added to produce an alkaline solution. The chromate concentration was determined by measuring the transmittancy of the solution at $367 \mathrm{~nm}(\mathrm{mu})$ of the solution in a $2-\mathrm{cm}$ cell and comparing to a reference curve.

The millimoles ( $\mathrm{m}$ mol) of lead present in the solution are equivalent to the millimoles of chromate added less the millimoles of chromate found in the filtrate. (The solubility of $\mathrm{PbCrO}_{4}$ under these conditions was found to be negligible.) Table 2 shows the results of these determinations.

TABLE 2. Concentration of lead isotope solutions

\begin{tabular}{|c|c|c|c|c|}
\hline Soln & $\begin{array}{c}\text { Sample } \\
\text { No. }\end{array}$ & Wt soln & $\begin{array}{c}\mathrm{K}_{2} \mathrm{Cr}_{2} \mathrm{O}_{7} \\
\text { Equivalent }\end{array}$ & $\begin{array}{l}\text { Conc. soln } \\
\mathrm{Pb} / \mathrm{g} \text { soln }\end{array}$ \\
\hline $\mathrm{Pb} 206 .$. & $\begin{array}{l}\text { A } \\
\text { B } \\
\text { C } \\
\text { D }\end{array}$ & $\begin{array}{c}g \\
7.99061 \\
8.24170 \\
8.00613 \\
7.86875\end{array}$ & $\begin{array}{c}\mathrm{mmol} \\
1.131165 \\
1.166716 \\
1.133361 \\
1.113944\end{array}$ & $\begin{array}{c}\text { mmol } \\
0.1415618 \\
.1415625 \\
.1415617 \\
.1415655\end{array}$ \\
\hline \multirow[t]{2}{*}{$\mathrm{Pb} 208 .}$. & $\begin{array}{l}\text { A } \\
\text { B } \\
\text { C } \\
\text { D }\end{array}$ & $\begin{array}{l}8.42849 \\
7.85653 \\
8.36411 \\
8.27248\end{array}$ & $\begin{array}{l}\text { Average } \\
1.186636 \\
1.106099 \\
1.177473 \\
1.164649\end{array}$ & $\begin{array}{r}\mathrm{a} 0.1415629 \\
0.1407887 \\
.1407872 \\
.1407768 \\
.1407860\end{array}$ \\
\hline & & & Average & 0.1407847 \\
\hline
\end{tabular}

a The standard error of the average is calculated to be 0.00000405 $\mathrm{mmol} \mathrm{Pb} / \mathrm{g}$ soln and the uncertainty of the value of concentration at the 95 percent confidence level is $0.0000081 \mathrm{mmol} \mathrm{Pb} / \mathrm{g}$ soln.

This method for determining the concentration of lead solutions was tested on solutions containing known amounts of lead. Nine such solutions, in the approximate concentration of the separated isotope solutions, were prepared from high purity lead containing less than 0.001 percent total detected metallic impurities. Four samples containing from 0.139 to $0.153 \mathrm{mmol}$ of $\mathrm{Pb}$ were withdrawn from each solution and the lead ion concentrations were determined as described.

Data resulting from the analysis of these nine preliminary lead solutions showed that (a) the concentrations of these solutions as mmol $\mathrm{Pb} / \mathrm{g}$ soln agreed to within 0.02 percent of the concentrations calculated, (b) a slight positive bias of 0.01 percent was detected but this would have a negligible effect on ratios, (c) the method was independent of sample size or concentration over the range studied, and (d) the analysis of the nine solutions were of equal precision.

Pooling the results of the analyses of the separated isotope solutions as shown in table 2 with the results from the nine sets described above yields a value of $0.0000081 \mathrm{mmol} \mathrm{Pb} / \mathrm{g}$ soln for the standard deviation of an individual determination (33 deg of freedom). The standard error of the average of four determina- 
tions is therefore $\frac{0.0000081}{2}$ or $0.00000405 \mathrm{mmol} \mathrm{Pb/g}$ soln. At the 95 percent confidence level this is equal to $2.04 \times 0.00000405$ or $0.000008 \mathrm{mmol} \mathrm{Pb} / \mathrm{g}$ soln.

\subsection{Isotopic Analysis of the Separated Isotope Solutions}

The separated isotope solutions were analyzed four times each on two mass spectrometers (\#2 and \#3). The averaged results are given in table 3 . In all of the analyses the amount of ${ }^{204} \mathrm{~Pb}$ could only be estimated because the signal was very small and could not be separated from possible baseline fluctuations with any degree of certainty. The isotopic compositions reported by ORNL are: "Pb 206 ", $<0.01$ atom percent ${ }^{204} \mathrm{~Pb}$, $99.8 \pm 0.02$ atom percent ${ }^{206} \mathrm{~Pb}, 0.2 \pm 0.02$ atom percent ${ }^{207} \mathrm{~Pb}$, and $<0.03$ atom percent ${ }^{208} \mathrm{~Pb}$; " $\mathrm{Pb} 208$ ", $<0.05$ atom percent ${ }^{204} \mathrm{~Pb}, 0.19 \pm 0.05$ atom percent ${ }^{206} \mathrm{~Pb}, 0.52 \pm 0.05$ atom percent ${ }^{207} \mathrm{~Pb}$, and $99.3 \pm 0.05$ atom percent ${ }^{208} \mathrm{~Pb}$. The ORNL limits quoted express the precision of the measurements. From known sources of systematic error, the absolute error is estimated by ORNL to be less than 1 percent.

TABLE 3. Isotopic composition of separated lead isotopes used in calibration samples

\begin{tabular}{|c|c|c|}
\hline \multicolumn{2}{|c|}{$\begin{array}{l}\text { Separated } \\
\text { isotope }\end{array}$} & \multirow{2}{*}{$\begin{array}{c}\begin{array}{c}\text { Isotopic composition } \\
\text { (atom percent) }\end{array} \\
0.0010 \\
99.7403 \pm 0.0040^{\text {a }} \\
0.2299 \\
.0288\end{array}$} \\
\hline "Pb 206" & $\begin{array}{l}{ }^{204} \mathrm{~Pb} \\
{ }^{206} \mathrm{~Pb} \\
{ }^{207} \mathrm{~Pb} \\
{ }^{208} \mathrm{~Pb}\end{array}$ & \\
\hline "Pb 208" & $\begin{array}{l}{ }^{204} \mathrm{~Pb} \\
{ }^{206} \mathrm{~Pb} \\
{ }^{207} \mathrm{~Pb} \\
{ }^{208} \mathrm{~Pb}\end{array}$ & $\begin{array}{r}0.0010 \\
.1930 \\
.5057 \\
99.3003 \pm 0.0040\end{array}$ \\
\hline
\end{tabular}

\footnotetext{
${ }^{\text {a }}$ The uncertainties are based on a minimum error of 0.00002 for the ratio determinations. The calculated 95 percent confidence limits are well below this value.
}

\subsection{Preparation of the Calibration Samples}

Six calibration samples were prepared by mixing weighed portions of the "Pb 206" solution and the "Pb 208" solution to approximate the compositions of the three reference materials. The target 208/206 ratios were $2.16,1.00$, and 0.014 . Two calibration samples were prepared for each target. However, since the errors associated with the preparation of mixes 7 and $8(208 / 206=0.014)$ were large, they were not used for calibration purposes. Each calibration sample was thoroughly mixed by stirring and evaporated to dryness. The sulting $\mathrm{Pb}\left(\mathrm{NO}_{3}\right)$ was taken into solution with sufficient 2 percent $\mathrm{HNO}_{3}$ so that the lead concentration was $25 \mathrm{mg} / \mathrm{ml}$. The compositions of these calibration samples are given in table 4 .
TABLE 4. Composition of lead calibration samples

\begin{tabular}{|c|c|c|c|c|}
\hline Sample & Isotope & $\mathrm{W}_{\mathrm{t}}$ soln & $\begin{array}{c}\text { Conc. soln } \\
\mathrm{Pb} / \mathrm{g} \text { soln }\end{array}$ & $\mathrm{Pb}$ \\
\hline 3 & $\begin{array}{l}206 \\
208\end{array}$ & $\begin{array}{c}g \\
2.02622 \\
2.08562\end{array}$ & $\begin{array}{c}m \mathrm{~mol} \\
0.1415629 \\
.1407847\end{array}$ & $\begin{array}{c}m \mathrm{~mol} \\
0.2868376 \\
.2936234\end{array}$ \\
\hline 4 & $\begin{array}{l}206 \\
208\end{array}$ & $\begin{array}{l}1.94738 \\
1.97846\end{array}$ & $\begin{array}{r}0.1415629 \\
.1407847\end{array}$ & $\begin{array}{r}0.2756768 \\
.2785369\end{array}$ \\
\hline 5 & $\begin{array}{l}206 \\
208\end{array}$ & $\begin{array}{l}0.97453 \\
2.10062\end{array}$ & $\begin{array}{r}0.1415629 \\
.1407847\end{array}$ & $\begin{array}{r}0.1379573 \\
.2957352\end{array}$ \\
\hline 6 & $\begin{array}{l}206 \\
208\end{array}$ & $\begin{array}{l}0.93376 \\
2.04303\end{array}$ & $\begin{array}{r}0.1415629 \\
.1407847\end{array}$ & $\begin{array}{r}0.1321858 \\
.2876274\end{array}$ \\
\hline 7 & $\begin{array}{l}206 \\
208\end{array}$ & $\begin{array}{l}4.12812 \\
0.05691\end{array}$ & $\begin{array}{r}0.1415629 \\
.1407847\end{array}$ & $\begin{array}{r}0.5843886 \\
.0080121\end{array}$ \\
\hline 8 & $\begin{array}{l}206 \\
208\end{array}$ & $\begin{array}{l}4.19283 \\
0.06345\end{array}$ & $\begin{array}{r}0.1415629 \\
.1407847\end{array}$ & $\begin{array}{r}0.5935492 \\
.0089328\end{array}$ \\
\hline
\end{tabular}

\subsection{Isotopic Analyses of the Calibration Mixes and Standard Samples}

Two complete sets of analyses of the calibration mixes and standard samples were made; one by operator I using instruments \#1 and \#3, and one by operator II using instrument \#2. In the case of the common lead and equal atom standards, each set consisted of a total of eight analyses of the standard and four analyses each of the two appropriate calibration mixes (mixes 3 and 4 for the common lead, and mixes 5 and 6 for the equal atom lead), run in a simple alternating pattern. In the case of the radiogenic standard each set also consisted of a total of eight analyses of the standard and four analyses each of two calibration mixes (mixes 7 and 8). However, subsequent statistical evaluation of the data showed that both the chemical error in the preparation of these very low ${ }^{208} \mathrm{~Pb} /{ }^{206} \mathrm{~Pb}$ mixes and the error in the measurements (minimum error on a ratio $=0.00002$ ) of these extreme ratios were too large, so that these mixes were essentially useless for calibration purposes. The principal source of the chemistry portion of the error was in the weighing and transferring of the small amounts of " $\mathrm{Pb} 208$ " solution $(\sim 60 \mathrm{mg})$. The results for these calibration mixes were therefore discarded and the final bias correction factor was calculated only on the basis of the four calibration mixes which had approximately the same ${ }^{208} \mathrm{~Pb} /{ }^{206} \mathrm{~Pb}$ values of either the common lead or equal atom standards.

In each standard sample analysis eight values each were obtained for the ${ }^{204} \mathrm{~Pb} /{ }^{206} \mathrm{~Pb},{ }^{207} \mathrm{~Pb} /{ }^{206} \mathrm{~Pb}$, and ${ }^{208} \mathrm{~Pb} /{ }^{206} \mathrm{~Pb}$ ratios in the order: four values of ${ }^{208} \mathrm{~Pb} /$ ${ }^{206} \mathrm{~Pb}$, four values of ${ }^{207} \mathrm{~Pb} /{ }^{206} \mathrm{~Pb}$, eight values of ${ }^{204} \mathrm{~Pb} /{ }^{206} \mathrm{~Pb}$, four values of ${ }^{207} \mathrm{~Pb} /{ }^{206} \mathrm{~Pb}$, and four values of ${ }^{208} \mathrm{~Pb} /{ }^{206} \mathrm{~Pb}$. This pattern was followed so that the data was symmetrical to any fractionation effect. In the analyses of the calibration mixes, twenty-four measurements of the ${ }^{208} \mathrm{~Pb} / 206 \mathrm{~Pb}$ ratio were taken over the normal data-taking time interval of a standard sample analysis. 
In all analyses, base-line readings were taken immediately before and after the data. The peak-top data were taken by step-wise changes in the magnet current and each peak-top was monitored for 30 sec.

\section{Results and Discussion}

Table 5 summarizes the results for the four calibration mixes. There is no statistically significant difference between any of the values. The seemingly large difference between operator II's values for mixes 5 and 6 and mixes 3 and 4 is probably the result of either an operator bias in base-line readings or an attenuator error.

Table 6 gives the observed and corrected ratios for the two sets of data. ${ }^{207} \mathrm{~Pb} /{ }^{206} \mathrm{~Pb}$ is corrected by
$1 / 2$ of the measured bias, and ${ }^{204} \mathrm{~Pb} /{ }^{206} \mathrm{~Pb}$ is corrected by the inverse of the measured bias. Table 7 gives the

TABLE 5. Determination of mass spectrometric bias

\begin{tabular}{|c|c|c|c|c|c|}
\hline \multirow{2}{*}{$\begin{array}{c}\text { Calibra- } \\
\text { tion } \\
\text { sample } \\
\text { No. }\end{array}$} & \multicolumn{3}{|c|}{ Isotopic ratio, ${ }^{208} \mathrm{~Pb} /{ }^{206} \mathrm{~Pb}$} & \multicolumn{2}{|c|}{ Correction factor } \\
\hline & $\begin{array}{l}\text { Calcu- } \\
\text { lated }\end{array}$ & $\underset{\text { I }}{\text { Operator }}$ & $\begin{array}{l}\text { Operator } \\
\text { II }\end{array}$ & $\begin{array}{l}\text { Operator } \\
\text { I }\end{array}$ & $\begin{array}{c}\text { Operator } \\
\text { II }\end{array}$ \\
\hline 3 & 1.017415 & 1.01677 & 1.01685 & 1.000634 & 1.000556 \\
\hline 4 & 1.004243 & 1.00378 & 1.00379 & 1.000461 & 1.000451 \\
\hline 5 & 2.125686 & 2.12462 & 2.12593 & 1.000502 & 0.999885 \\
\hline 6 & 2.117538 & 2.15718 & 2.15798 & 1.000166 & .999795 \\
\hline \multicolumn{4}{|c|}{ Mean values of correction factors... } & 1.000441 & 1.000172 \\
\hline
\end{tabular}

TABLE 6. Observed and corrected isotopic ratios for the standard samples

\begin{tabular}{l|c|r|r|r|r|r|r}
\hline \multirow{2}{*}{ Sample } & \multirow{2}{*}{ Operator } & \multicolumn{3}{|c|}{ Observed ratios } & \multicolumn{3}{c}{ Corrected ratios } \\
\cline { 3 - 8 } & & ${ }^{204} \mathrm{~Pb} /{ }^{206} \mathrm{~Pb}$ & ${ }^{207} \mathrm{~Pb} /{ }^{206} \mathrm{~Pb}$ & ${ }^{208} \mathrm{~Pb} /{ }^{206} \mathrm{~Pb}$ & ${ }^{204} \mathrm{~Pb} /{ }^{206} \mathrm{~Pb}$ & ${ }^{207} \mathrm{~Pb} /{ }^{206} \mathrm{~Pb}$ & ${ }^{208} \mathrm{~Pb} /{ }^{206} \mathrm{~Pb}$ \\
\hline & & & & & & & \\
Common & I & 0.059067 & 0.91437 & 2.1669 & 0.059041 & 0.91457 & 2.1678 \\
SRM 981 & II & .059053 & .91465 & 2.1680 & .059043 & .91472 & 2.1684 \\
Equal-Atom & I & 0.027223 & 0.46679 & 0.99964 & 0.027211 & 0.46689 & 1.00009 \\
SRM 982 & II & .027232 & .46721 & 1.00007 & .027227 & .46725 & 1.00024 \\
Radiogenic & I & 0.0003723 & 0.071178 & 0.013611 & 0.0003721 & 0.071194 & 0.013617 \\
SRM 983 & II & .0003693 & .071202 & .013619 & .0003692 & .071208 & .013621 \\
\hline
\end{tabular}

TABLE 7. Absolute isotopic ratios for the three standard samples

\begin{tabular}{|c|c|c|c|}
\hline & ${ }^{204} \mathrm{~Pb} /{ }^{206} \mathrm{~Pb}$ & ${ }^{207} \mathrm{~Pb} /{ }^{206} \mathrm{~Pb}$ & ${ }^{208} \mathrm{~Pb} /{ }^{206} \mathrm{~Pb}$ \\
\hline Common Lead (SRM 981).... & 0.059042 & 0.91464 & 2.1681 \\
\hline Overall limit of error ${ }^{a} \ldots \ldots \ldots \ldots \ldots \ldots \ldots \ldots \ldots$ & \pm 0.000037 & \pm 0.00033 & \pm 0.0008 \\
\hline Uncertainty Components: & & & \\
\hline $\begin{array}{l}95 \% \text { confidence limits on ratio determination (min- } \\
\text { imum }=0.00002) \ldots \ldots \ldots \ldots \ldots \ldots \ldots \ldots \ldots \ldots\end{array}$ & \pm 0.000020 & \pm 0.00007 & \pm 0.0002 \\
\hline 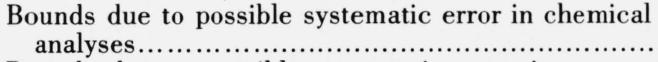 & \pm 0.000005 & \pm 0.00007 & \pm 0.0002 \\
\hline $\begin{array}{l}\text { Bounds due to possible systematic error in correc- } \\
\text { tion factor (including errors in separated isotopes). }\end{array}$ & \pm 0.000012 & \pm 0.00019 & \pm 0.0004 \\
\hline Equal-Atom Lead (SRM 982). . & 0.027219 & 0.46707 & 1.00016 \\
\hline $\begin{array}{l}\text { Overall limit of error...................... } \\
\text { Uncertainty Components: }\end{array}$ & \pm 0.000027 & \pm 0.00020 & \pm 0.00036 \\
\hline $\begin{array}{l}95 \% \text { confidence limits on ratio determination (mini- } \\
\text { mum }=0.00002) \ldots \ldots \ldots \ldots \ldots \ldots \ldots \ldots \ldots \ldots \ldots \ldots \ldots \ldots \ldots \ldots \ldots \ldots \ldots \ldots \ldots \ldots\end{array}$ & \pm 0.000020 & \pm 0.00006 & \pm 0.00007 \\
\hline 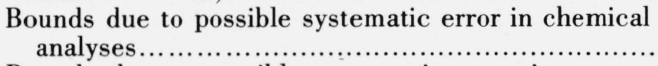 & \pm 0.000002 & \pm 0.00004 & \pm 0.00008 \\
\hline $\begin{array}{l}\text { Bounds due to possible systematic error in correc- } \\
\text { tion factor (including errors in separated isotopes). }\end{array}$ & \pm 0.000005 & \pm 0.00010 & \pm 0.00021 \\
\hline Radiogenic Lead (SRM 983).. & 0.000371 & 0.071201 & 0.013619 \\
\hline $\begin{array}{l}\text { Overall limit of error......................................... } \\
\text { Uncertainty Components: }\end{array}$ & \pm 0.000020 & \pm 0.000040 & \pm 0.000024 \\
\hline $\begin{array}{l}95 \% \text { confidence limits on ratio determination (mini- } \\
\text { mum }=0.00002) \ldots \ldots \ldots \ldots \ldots \ldots \ldots \ldots \ldots \ldots \ldots \ldots \ldots\end{array}$ & \pm 0.000020 & \pm 0.000020 & \pm 0.000020 \\
\hline 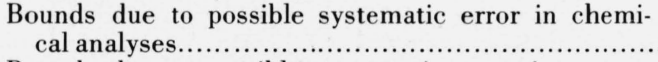 & \pm 0.000000 & \pm 0.000006 & \pm 0.000001 \\
\hline $\begin{array}{l}\text { Bounds due to possible systematic error in correc- } \\
\text { tion factor (including errors in separated isotopes)... }\end{array}$ & \pm 0.000000 & \pm 0.000014 & \pm 0.000003 \\
\hline
\end{tabular}

a The overall limit of error is the sum of the 95 percent confidence limits for the ratio determinations and the terms covering effects of known sources of possible systematic error. 
TABLE 8. Atom percents and atomic weights for the three standard samples

\begin{tabular}{|c|c|c|c|c|}
\hline & \multirow{2}{*}{$\begin{array}{l}\text { Overall limit } \\
\text { of error }^{\mathrm{a}}\end{array}$} & \multicolumn{3}{|c|}{ Uncertainty components } \\
\hline & & $\begin{array}{l}\text { Mass spectrometric } \\
\text { analytical error }\end{array}$ & $\begin{array}{l}\text { Possible systematic } \\
\text { error in chemical } \\
\text { analysis }\end{array}$ & $\begin{array}{l}\text { Possible systematic } \\
\text { error in composition } \\
\text { of separated isotopes }\end{array}$ \\
\hline $\begin{array}{l}\text { Common Lead (SRM 981) } \\
\text { Atomic weight..... 207.2152... }\end{array}$ & \pm 0.00015 & \pm 0.00004 & \pm 0.00003 & \pm 0.00008 \\
\hline 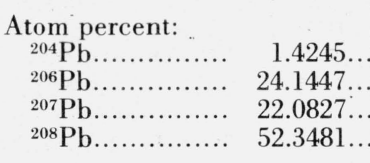 & $\begin{array}{l} \pm 0.0012 \\
\pm 0.0057 \\
\pm 0.0027 \\
\pm 0.0086\end{array}$ & $\begin{array}{l} \pm 0.0005 \\
\pm 0.0014 \\
\pm 0.0019 \\
\pm 0.0028\end{array}$ & $\begin{array}{l} \pm 0.0002 \\
\pm 0.0012 \\
\pm 0.0002 \\
\pm 0.0016\end{array}$ & $\begin{array}{l} \pm 0.0005 \\
\pm 0.0031 \\
\pm 0.0006 \\
\pm 0.0042\end{array}$ \\
\hline $\begin{array}{l}\text { Equal-Atom Lead (SRM 982) } \\
\text { Atomic weight..... 206.9429... }\end{array}$ & \pm 0.00014 & \pm 0.00003 & \pm 0.00003 & \pm 0.00008 \\
\hline 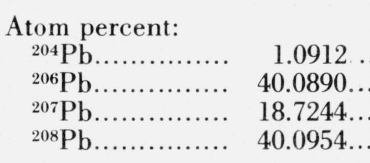 & $\begin{array}{l} \pm 0.0012 \\
\pm 0.0072 \\
\pm 0.0023 \\
\pm 0.0077\end{array}$ & $\begin{array}{l} \pm 0.0008 \\
\pm 0.0015 \\
\pm 0.0022 \\
\pm 0.0019\end{array}$ & $\begin{array}{l} \pm 0.0001 \\
\pm 0.0016 \\
\pm 0.0000 \\
\pm 0.0016\end{array}$ & $\begin{array}{l} \pm 0.0003 \\
\pm 0.0041 \\
\pm 0.0001 \\
\pm 0.0042\end{array}$ \\
\hline $\begin{array}{l}\text { Radiogenic Lead (SRM 983) } \\
\text { Atomic weight..... 206.0646.. }\end{array}$ & \pm 0.00009 & \pm 0.00006 & \pm 0.00001 & \pm 0.00002 \\
\hline 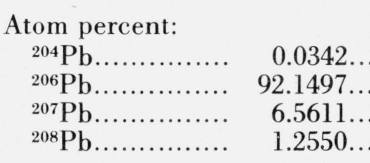 & $\begin{array}{l} \pm 0.0020 \\
\pm 0.0041 \\
\pm 0.0025 \\
\pm 0.0022\end{array}$ & $\begin{array}{l} \pm 0.0020 \\
\pm 0.0029 \\
\pm 0.0017 \\
\pm 0.0018\end{array}$ & $\begin{array}{l} \pm 0.0000 \\
\pm 0.0003 \\
\pm 0.0002 \\
\pm 0.0001\end{array}$ & $\begin{array}{l} \pm 0.0000 \\
\pm 0.0009 \\
\pm 0.0006 \\
\pm 0.0003\end{array}$ \\
\hline \multicolumn{4}{|c|}{ Nuclidic Masses: 203.973044, 205.974468, 206.975903, 207.976650} & \\
\hline
\end{tabular}

a The overall limit of error is the sum of the 95 percent confidence limits for the ratio determinations and the terms covering effects of known sources of possible systematic error.

final absolute values for all of the ratios along with the overall limits of error and uncertainty components. The precision was essentially the same for both sets of data, so the final values are straight averages of the two sets. Because of instrumental uncertainties, such as dead zone and recorder nonlinearity, it is assumed that no ratio can be measured to better than 0.00002 ; so this figure is used as an error value whenever the statistically determined 95 percent confidence limit is smaller than 0.00002 .

Table 8 gives the atomic percents for each of the isotopes in each standard sample, and the atomic weights $\left({ }^{12} \mathrm{C}=12\right)$ of each standard. Nuclidic masses were taken from Mattauch et al. [13].

We are indebted to Mrs. Martha Darr for the quantitative spectrochemical analyses of the lead isotope samples and to Hsien $\mathrm{H}$. Ku for the statistical analysis of the experimental data.

\section{Appendix}

A catalog listing all of the NBS Standard Reference Materials, including Isotopic Standards, may be obtained from the Superintendent of Documents, U.S. Government Printing Office, Washington, D.C. 20402. The serial number of the catalog is: NBS
Miscellaneous Publication 260. The price is 45 cents. Aliquots of the lead isotope standards described in this paper may be purchased from the NBS in the following manner. Orders should be addressed to the Office of Standard Reference Materials, National Bureau of Standards, Washington, D.C. 20234. The order should stipulate: $1 \mathrm{~g}$ each of NBS SRM Nos. 981, 982, and 983 (lead isotope reference standards). The price is $\$ 100$ per set and they are only sold as a set.

The isotopic compositions of the uranium-isotope standards are given in the table below. These materials are sold individually in $\mathrm{l}-\mathrm{g}$ units of $\mathrm{U}_{3} \mathrm{O}_{8}$. Prices range from $\$ 37.50 /$ unit for U005 to $\$ 54.50 /$ unit for U930.

NBS best estimate from pooled data of isotopic composition of uranium standards (atom \%)

\begin{tabular}{c|r|r|r|r|l}
\hline \hline $\begin{array}{c}\text { SRM } \\
\text { No. }\end{array}$ & U234 & U235 & U236 & U238 & $235 / 238$ \\
\hline & & & & & \\
\hline U005 & 0.0022 & 0.4896 & 0.0047 & 99.5035 & 0.004920 \\
U010 & .0054 & 1.0038 & .0068 & 98.9840 & .010141 \\
U015 & .0085 & 1.5322 & .0164 & 98.4429 & .015564 \\
U020 & .0125 & 2.0383 & .0165 & 97.9327 & .020813 \\
U030 & .0190 & 3.0459 & .0204 & 96.9147 & .031429 \\
U050 & .0279 & 5.0089 & .0480 & 94.9152 & .05277 \\
\hline
\end{tabular}


NBS certified values (atom \%)

\begin{tabular}{l|r|r|r|r|r}
\hline U100 & 0.0676 & 10.190 & 0.0379 & 89.704 & 0.11360 \\
U150 & .0993 & 15.307 & .0660 & 84.528 & .18109 \\
U200 & .1246 & 20.013 & .2116 & 79.651 & .25126 \\
U350 & .2498 & 35.190 & .1673 & 64.393 & .5465 \\
U500 & .5181 & 49.696 & .0755 & 49.711 & .9997 \\
U750 & .5923 & 75.357 & .2499 & 23.801 & 3.166 \\
U800 & .6563 & 80.279 & .2445 & 18.820 & 4.266 \\
U850 & .6437 & 85.137 & .3704 & 13.848 & 6.148 \\
U900 & .7777 & 90.196 & .3327 & 8.693 & 10.375 \\
U930 & 1.0812 & 93.336 & .2027 & 5.380 & 17.349 \\
\hline
\end{tabular}

\section{References}

[1] W. R. Shields, E. L. Garner, and V. H. Dibeler, J. Res. NBS 66A (Phys. and Chem.), No. 1, l (1962).

[2] W. R. Shields, T. J. Murphy, E. L. Garner, and V. H. Dibeler, J. Am. Chem. Soc. 84, 1519 (1962).

[3] W. R. Shields, T. J. Murphy, and E. L. Garner, J. Res. NBS, 68A (Phys. and Chem.), No. 6, 589 (1964).
[4] E. J. Catanzaro, T. J. Murphy, E. L. Garner, and W. R. Shields, J. Res. NBS 68A (Phys. and Chem.), No. 6, 593 (1964).

[5] W. R. Shields, T. J. Murphy, E. J. Catanzaro, and E. L. Garner, J. Res. NBS 70A (Phys. and Chem.), No. 2, 193 (1966).

[6] E. J. Catanzaro, T. J. Murphy, E. L. Garner, and W. R. Shields, J. Res. NBS 70A (Phys. and Chem.), No. 6, 453 (1966).

[7] R. D. Russell and R. M. Farquhar, Lead Isotopes in Geology (Interscience, New York, 1960).

[8] E. J. Catanzaro, Earth and Plan. Sci. Letters 3, No. 4, 343. (1968).

[9] W. R. Shields, editor, NBS Tech. Note 426 (1967).

[10] E. J. Catanzaro, J. Geophys. Res. 72, No. 4, 1325 (1967).

[11] G. Marienko and J. K. Taylor, J. Res. NBS 67A (Phys. and Chem.), No. 5, 453 (1963).

[12] B. K. N. Murthy, Pro. of Indian Acad. Sci. 31A, 160 (1950).

[13] J. H. E. Mattauch, W. Thiele, and A. H. Wapstra, Nuclear Physics 67, 1 (1965).

(Paper 72A3-500) 